\begin{tabular}{|c|c|}
\hline Citation & $\begin{array}{l}\text { Schaevers, V., Schoonis, A. (2012), } \\
\text { Implementing a standardized, evidence-based education program using } \\
\text { the patient's electronic file for lung transplant recipients } \\
\text { Progress in Transplantation, 22(3), } 264-270\end{array}$ \\
\hline Archived version & Final publisher's version / pdf \\
\hline Published version & http://dx.doi.org/10.7182/pit2012366 \\
\hline Journal homepage & http://www.natco1.org/Publications/progress-in-transplantation.asp \\
\hline Author contact & $\begin{array}{l}\text { Fabienne.dobbels@med.kuleuven.be } \\
+32(0) 16373402\end{array}$ \\
\hline IR & https://lirias.kuleuven.be/cv?u=U0015258 \\
\hline
\end{tabular}

(article begins on next page) 


\section{Implementing a standardized, evidence-based education program using the patient's electronic file for lung transplant recipients}

Context-Patient education is crucial to guarantee that transplant recipients are capable of adequate self-management. Until recently, our education program to prepare lung transplant patients for discharge lacked a systematic approach, meaning that it was unclear whether all key information had been provided and whether the patient understood the information. A lack of coordination among the multidisciplinary team members also was apparent.

Objectives - (1) To map out a structured education program, outlining the content, process, and evaluation of education for patients before discharge after lung transplant; (2) to integrate this program into the patient's electronic file and pilot test this new form of education tracking.

Methods - We used the conceptual framework of Lorig and colleagues, as well as the educational leaflets of the International Transplant Nurses Society, to generate the content of our education program. The interdisciplinary lung transplant team decided when and by whom each educational component should be provided, as well as the evaluation criteria. Next, information technology engineers integrated this educational program into the patient's electronic file. Nurses subsequently tested the program, and their feedback was integrated in the next version of the program.

Results - Health care providers experienced a higher level of uniformity and transparency. After using the education program, most patients indicated that they felt confident to go home.

Conclusion-Our electronic educational platform is promising, yet further testing is necessary to evaluate whether patients indeed have sufficient knowledge and show adequate self-management skills in the long term after transplant. (Progress in Transplantation. 2012;22:264-270)

(C2012 NATCO, The Organization for Transplant Professionals doi: http://dx.doi.org/10.7182/pit2012366

\author{
Veronique Schaevers, MSN, \\ Annemie Schoonis, BSN, \\ Gerrit Frickx, BSN, Geert \\ Verleden, MD, PhD, Christel \\ Jans, MSN, Chris Rosseel, \\ BSN, Mieke Meelberghs, \\ BSN, Inge Reinquin, MSN, \\ Fabienne Dobbels, PhD, for \\ the Interdisciplinary Lung \\ Transplantation Team and \\ the Information Technology \\ Engineers \\ University Hospital, Leuven, Belgium
}

Corresponding author: Veronique Schaevers, MSN, CNS, Lung Transplantation Unit, University Hospital, 49 Herestraat, B-3000 Leuven, Belgium (e-mail: veronique.schaevers@uzleuven.be)

To purchase electronic or print reprints, contact:

The InnoVision Group

101 Columbia, Aliso Viejo, CA 92656

Phone (800) 899-1712 (ext 532) or

(949) 448-7370 (ext 532)

Fax (949) 362-2049

E-mail reprints@aacn.org
$\mathrm{L}$ ung transplant has emerged as a suitable treatment option for selected patients with end-stage lung disease, offering improved survival rates and a better quality of life. However, the underlying disease and the transplant surgery have a great impact on morbidity, mortality, quality of life, and psychological and social functioning of patients. ${ }^{1-11}$ The lung transplant population is also characterized by high medical consumption, including frequent hospitalizations and outpatient consultations on a regular basis. That is why lung transplant needs to be regarded as a chronic condition calling for an adapted approach to address the patient's needs.
We believe that the successes of lung transplant are made possible, not only thanks to the increased surgical and medical experience, but also to an intense and lifelong interdisciplinary follow-up.

Preparing patients for adequate self-management immediately after transplant is one of the most important and challenging goals. Lorig and colleagues ${ }^{11-13}$ stated that patients are active partners in their treatment and are responsible for managing the disease in their daily life, that is, far away from the hospital. Selfmanagement aims at helping patients to maintain and improve their chronic condition and concentrates on 3 sets of tasks. The first set of tasks involves the medical 
management of the condition, for example, taking medication, adhering to a special diet, and exercising regularly. The second set of tasks involves maintaining, changing, and creating (new) meaningful life roles. The final set of tasks refers to dealing with the emotions associated with having a chronic condition.

To be able to carry out these tasks adequately, patients must acquire self-management skills including problem solving, decision making, resource utilization, forming of a partnership with the health care provider, and taking action. However, before these skills can be trained, patients need sufficient knowledge about their disease and treatment, as well as why these self-management tasks are important for longterm survival and quality of life. In other words, education is a necessary condition to guarantee excellent self-management skills.

In many settings, patients receive only oral information on topics like medications, importance of sustained smoking cessation, and organization of follow-up visits. Providing education to transplant recipients is not a 1-person job. Several health care providers are involved in the education process. Although patients often receive an education brochure, it is unclear which information was given to patients, at what time, and by whom. Also, does the patient understand the information that was given or is reinforcement of the education indicated? Consequently, health care providers give patient education based on their own experiences and opinions. Thus, the quality of the education strongly depends on the person who provides the education.

We also noticed that, from a multidisciplinary point of view, there often is too little transparency between the different disciplines. This lack of transparency results in overlap of information provided by different disciplines on the one hand and gaps in the information on the other hand. At the same time, the number of patients undergoing transplant has increased significantly, leaving less time, fewer resources, and fewer staff to provide patients all the necessary information. To illustrate, the number of lung transplants at our center almost tripled during the past 10 years (from 20 lung transplant recipients in 2000 to 58 lung transplant recipients in 2010). Currently lung transplant patients stay in the hospital for approximately 35 days immediately after the transplant surgery, of which 15 days are spent in the regular transplant care area, during which education before discharge is provided. The current 15-day stay is a much shorter stay than in the earlier years of our program.

We identified the need for a structured education program immediately after transplant that could help patients prepare for a successful discharge from the hospital. The aims of this practice-improvement project were (1) to develop a standardized, evidence-based education program and (2) to integrate this program into the patient's electronic file. By doing so, we wanted to create uniformity in the content of the education provided by nurses and allied health professionals, and subsequently improve patients' satisfaction, knowledge, and self-management. This article describes how this program was developed, its content, and how the electronic platform has advantages over traditional oral education.

\section{Methods}

\section{Mapping the Content of the Posttransplant Education for Lung Transplant Patients}

To determine what patients need to know after transplant and what topics need to be included in the education plan, we used the following educational brochures developed by the International Transplant Nurses Society as a starting point:

-Sexual Health After Transplant: What Every Patient Should Know

- Diet and Exercise After Transplant

-What Every Patient Needs to Know About Dental Care

- Maintaining a Healthy Lifestyle After Transplantation

- Controlling Gastrointestinal Side Effects After Transplant: What Every Patient Should Know

- Skin Cancer Risks in Transplant Recipients: Know the Facts

The content of these brochures was summarized, and all aspects were carefully discussed during several meetings of the multidisciplinary team. These discussions were led by an advanced practice nurse. Topics discussed were the appropriateness of the educational content for the Leuven program, the evaluation criteria, and who is responsible for which aspect of the education. The topics used in the standardized education program were divided into 2 groups: knowledge and skills-related topics. Knowledge addresses what every patient needs to know. Skills refers to what every patient should be able to do.

The final education program consists of the list of topics to be addressed, the content, the timing of the training, and the educator responsible for each part of the education (see Table).

The education program starts when patients can be transferred from the intensive care unit to the transplant hospitalization unit. Transplant recipients remain on this unit for a mean of 15 days. The time needed to complete the education program is tailored to this 2week period. Every topic of the education program is planned on a particular postoperative day. This way, members of the transplant team have some guidance on what knowledge the patients should have acquired at a certain point in time during their predischarge preparation. However, the program can be adjusted to the patient's individual needs as some patients learn 


\section{Schaevers et al}

Table Topics about which patients need to be educated after lung transplantation

\begin{tabular}{|c|c|c|c|c|}
\hline Day & Topic to be addressed & Criteria used to evaluate & Content of topic & Responsible educator \\
\hline 1 & Dental care & $\begin{array}{l}\text { Patient received information } \\
\text { regarding dental care }\end{array}$ & $\begin{array}{l}\text { Rinse } 4 \text { times a day with nystatin } \\
\text { and antimicrobial mouthwash } \\
\text { Floss and brush teeth } 2 \times / \text { day } \\
\text { Store toothbrush and dental } \\
\text { prosthesis dry } \\
\text { Change toothbrush every } 3 \\
\text { months } \\
\text { Wash toothbrush and dental } \\
\text { prosthesis thoroughly } \\
\text { Visit dentist at least every } 6 \\
\text { months }\end{array}$ & Registered nurse \\
\hline
\end{tabular}

$2 \quad$ Hygiene $\begin{aligned} & \text { Patient understands which aspects } \\ & \text { are important in view of daily } \\ & \text { hygiene }\end{aligned}$

Daily clean underwear

Change towels and washcloths

Registered nurse 2 times a week

Wash hair 2 times a week

Preferably shower instead of bath

Preferably use $\mathrm{pH}$-neutral soap

3 Medication Patient is able to use the
medication diary

Write down medication schedule Registered nurse daily

Write down body temperature

2 times a day

Write down lung function values

(spirometry) 2 times a day

Write down weight 1 time a week

Write down comments/problems when necessary

$5 \quad$ Medication $\quad \begin{gathered}\text { Patient knows the name and } \\ \text { purpose of the medication }\end{gathered}$

5 main groups: immunosuppressive medication, antibiotic

Registered nurse prophylaxis, osteoporosis medication, antacids, antihypertensive drugs

The importance of medication adherence and the consequences of nonadherence

\begin{tabular}{|c|c|c|c|c|}
\hline \multirow[t]{3}{*}{8} & Diet & $\begin{array}{l}\text { Patient knows what he or she } \\
\text { can and cannot eat }\end{array}$ & $\begin{array}{l}\text { First } 3 \text { months germ reduction } \\
\text { (no raw fish/meat; preferably } \\
\text { peeled fruit/vegetables) } \\
\text { Afterwards eat foods lower in } \\
\text { saturated fats }\end{array}$ & Dietician \\
\hline & Medication & $\begin{array}{l}\text { The patient is able to store } \\
\text { medication in the correct way }\end{array}$ & $\begin{array}{l}\text { Keep tacrolimus/cyclosporine in } \\
\text { blister pack until just before } \\
\text { intake } \\
\text { Keep your medication box in a dry } \\
\text { place with not too much light }\end{array}$ & Registered nurse \\
\hline & & $\begin{array}{l}\text { Patient is able to manage and } \\
\text { organize a stock of medication }\end{array}$ & $\begin{array}{l}\text { Keep medication box clean and } \\
\text { well organized } \\
\text { Order medication on time } \\
\text { Take expiration date into account }\end{array}$ & Registered nurse \\
\hline \multirow[t]{2}{*}{10} & Lifestyle & $\begin{array}{l}\text { Patient knows which precautions } \\
\text { to take during sun exposure }\end{array}$ & $\begin{array}{l}\text { Avoid direct exposure to the sun } \\
\text { Sun cream with minimum sun } \\
\text { protection factor of } 15 \\
\text { Solarium is forbidden } \\
\text { Self-tanner is allowed, but is not } \\
\text { sun protection } \\
\text { Visit a dermatologist every year } \\
\text { to check moles }\end{array}$ & Clinical nurse specialist \\
\hline & & $\begin{array}{l}\text { Patient knows the precautions and } \\
\text { risks of smoking and second- } \\
\text { hand smoking }\end{array}$ & $\begin{array}{l}\text { Increased risk of chronic rejection } \\
\text { Increased risk of cancer } \\
\text { developing } \\
\text { In case of severe chronic rejection, } \\
\text { no option for retransplant }\end{array}$ & Psychologist \\
\hline
\end{tabular}


Table Continued

\begin{tabular}{|c|c|c|c|c|}
\hline Day & Topic to be addressed & Criteria used to evaluate & Content of topic & Responsible educator \\
\hline \multirow[t]{4}{*}{10} & \multirow[t]{3}{*}{ Lifestyle } & $\begin{array}{l}\text { Patient received information } \\
\text { about sexuality }\end{array}$ & $\begin{array}{l}\text { Allowed when patient is ready } \\
\text { Erectile dysfunction, vaginal warts } \\
\text { regularly occur }\end{array}$ & Psychologist \\
\hline & & $\begin{array}{l}\text { Patient received information } \\
\text { regarding driving/transport }\end{array}$ & $\begin{array}{l}\text { Permission after } 8 \text { weeks } \\
\text { Driving certificate } \\
\text { Options for transportation to and } \\
\text { from the hospital }\end{array}$ & Social worker \\
\hline & & $\begin{array}{l}\text { Patient received information } \\
\text { regarding traveling }\end{array}$ & $\begin{array}{l}\text { Keep medication in carry-on baggage } \\
\text { Holidays by car allowed after } 3 \\
\text { months, by plane after } 6 \text { months } \\
\text { Carry transplantation identification } \\
\text { card in wallet } \\
\text { Ask for list of transplant centers in } \\
\text { the area } \\
\text { Check quality of food and water }\end{array}$ & Clinical nurse specialist \\
\hline & Medication & $\begin{array}{l}\text { Patient knows what to do } \\
\text { when medication is forgot- } \\
\text { ten, or in case of overdose } \\
\text { or vomiting }\end{array}$ & $\begin{array}{l}\text { Contact the transplant nurse of the } \\
\text { outpatient clinic } \\
\text { For vomiting immediately after med- } \\
\text { ication intake: take the whole dose } \\
\text { For vomiting within the hour after } \\
\text { medication intake: take half the dose } \\
\text { For vomiting more than } 1 \text { hour after } \\
\text { medication intake: no further } \\
\text { actions } \\
\text { Severe mistakes with medication } \\
\text { intake: immediately contact the } \\
\text { transplant physician and/or go to } \\
\text { nearest emergency department }\end{array}$ & Clinical nurse specialist \\
\hline 12 & Sports and exercise & $\begin{array}{l}\text { Patient knows which sports } \\
\text { are and are not allowed }\end{array}$ & $\begin{array}{l}\text { Lifting heavy weights after } 6 \text { weeks } \\
\text { Swimming allowed after } 3 \text { months if } \\
\text { all wounds are healed } \\
\text { Subtropical pools/saunas are } \\
\text { forbidden } \\
\text { Contact sports (eg, karate, boxing) } \\
\text { are forbidden } \\
\text { Extreme sports (eg, bungie jumping) } \\
\text { require the advice of the transplant } \\
\text { physician }\end{array}$ & Physiotherapist \\
\hline 13 & Follow-up & $\begin{array}{l}\text { Patient knows how follow-up } \\
\text { is organized }\end{array}$ & $\begin{array}{l}\text { Opening hours of the outpatient } \\
\text { clinic } \\
\text { Planning of the outpatient clinic day } \\
\text { Information about the nursing, tech- } \\
\text { nical, and physical consultations }\end{array}$ & Clinical nurse specialist \\
\hline \multirow[t]{5}{*}{14} & \multirow[t]{5}{*}{ Comorbid conditions } & $\begin{array}{l}\text { Patient is able to recognize } \\
\text { the signs and symptoms of } \\
\text { infection }\end{array}$ & $\begin{array}{l}\text { Body temperature }>37.5^{\circ} \mathrm{C} \text {, coughing, } \\
\text { shortness of breath, fatigue, diar- } \\
\text { rhea, vomiting }\end{array}$ & \multirow[t]{5}{*}{$\begin{array}{l}\text { Registered nurse and } \\
\text { clinical nurse specialist }\end{array}$} \\
\hline & & $\begin{array}{l}\text { Patient is able to recognize } \\
\text { the signs and symptoms of } \\
\text { rejection }\end{array}$ & $\begin{array}{l}\text { Decreased lung function, body tem- } \\
\text { perature }>37.5^{\circ} \mathrm{C} \text {, fatigue, possibly } \\
\text { lower fever }\end{array}$ & \\
\hline & & \multirow[t]{2}{*}{$\begin{array}{l}\text { Patient knows how to respond } \\
\text { to suspected infection }\end{array}$} & $\begin{array}{l}\text { No analgesics that are based on } \\
\text { acetylsalicylic acid and aceta- } \\
\text { minophen (mask temperature) } \\
\text { Contact the transplant nurse of the } \\
\text { outpatient clinic }\end{array}$ & \\
\hline & & & $\begin{array}{l}\text { Extra home monitoring of lung } \\
\text { function }\end{array}$ & \\
\hline & & $\begin{array}{l}\text { Patient knows how to respond } \\
\text { to suspected rejection }\end{array}$ & $\begin{array}{l}\text { Contact the transplant nurse of the } \\
\text { outpatient care clinic and/or the } \\
\text { transplant physician }\end{array}$ & \\
\hline
\end{tabular}




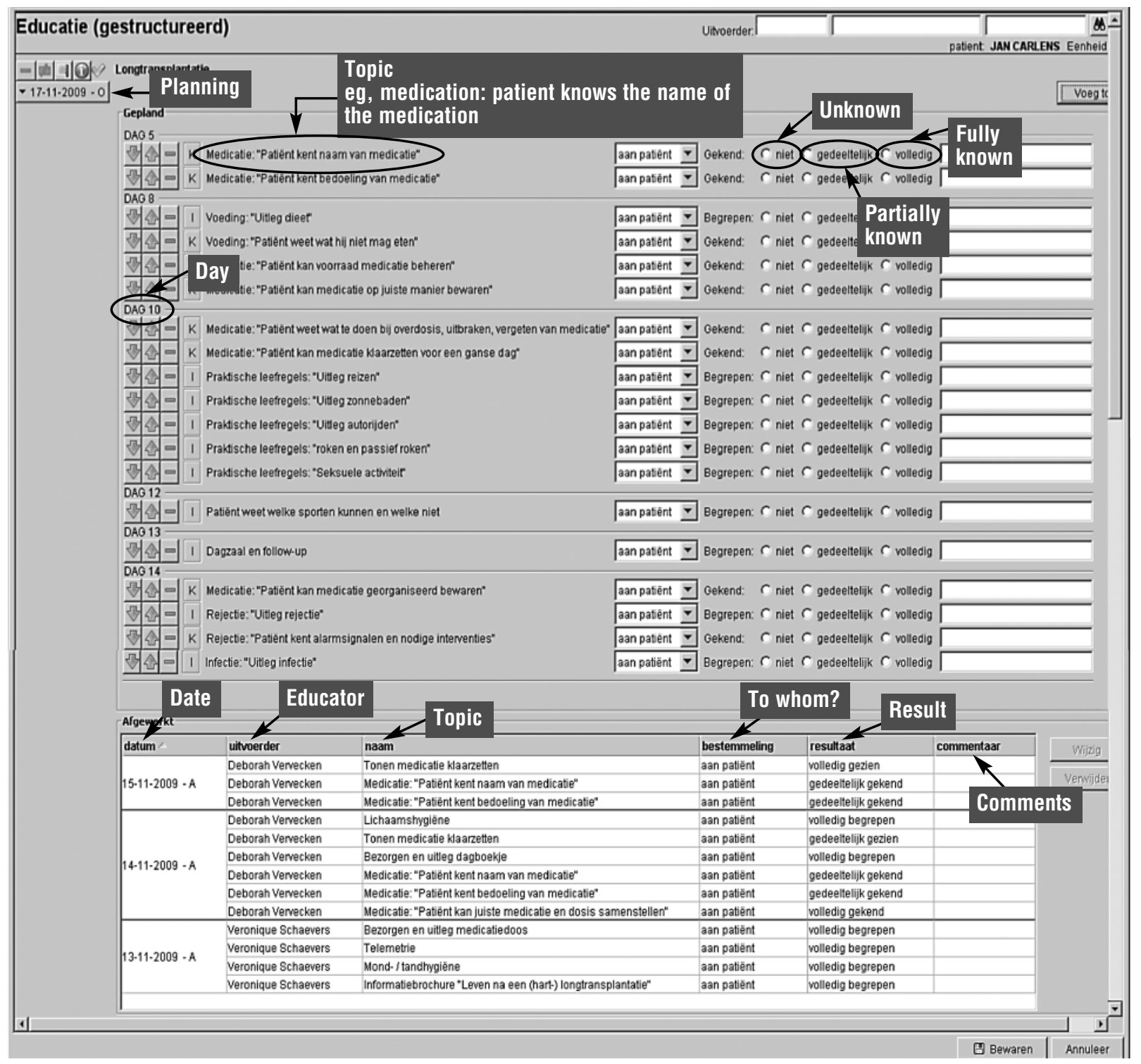

Figure Snapshot of the education program within a patient's electronic file.

more quickly than others, or when medical complications prevent team members from starting the education. That is why the health care provider can easily change the date of certain topics.

The first week of the education program is mainly focused on hygiene and medication because patients are confronted with these topics immediately after transplant. During the last week of the education program, topics regarding diet, follow-up, lifestyle, sports, comorbid conditions, and dental care are emphasized because knowledge on these topics is more relevant for the patient's life at home. The program also shows the different names of the health care providers, which makes it easy to find out who is responsible for a given topic.

Finally, the health care provider needs to evaluate the effectiveness of the education. Team members ask a patient to repeat the information provided in their own words. Three possible responses can be chosen for each aspect of the educational topic a patient should know: (1) The patient cannot recall the educational content. (2) The patient knows the information only partially. (3) The patient knows it completely. In case of responses 1 and 2, follow-up or repetition of the education is warranted until response 3 is obtained. To illustrate this, when the topic "dental care" is presented, the following mandatory topics should be stated or demonstrated by the patient: flossing and brushing teeth at least 2 times a day, visiting the dentist at least every 6 months, informing the dentist about the transplant and medication, changing toothbrush every 3 months, storing the toothbrush and dental prosthesis dry, and washing the toothbrush and dental prosthesis thoroughly. All this information is summarized at the bottom of the education program (see Figure). 
Programming the Education Plan Into the Patient's Electronic File

Choice of the right format to prepare our patients for adequate self-management demands a process for assessing the target group, the objectives, and the available materials. Team members involved in the education were convinced that having an electronic system would allow them to access the education plan easily.

In our hospital, electronic files are increasingly used to store and exchange medical information, results of nursing care, and multidisciplinary evaluations, and our goal is to completely replace paper versions of medical files in the upcoming months. First, a team of information technology engineers, a clinical nurse specialist, the head nurse, and specialized transplant nurses developed "the hospitalization posttransplant" program for patients who received a lung transplant and are stable enough to leave the intensive care unit. This program contains all items that comprise the total care of patients such as monitoring vital signs, personal hygiene, wound care, and mobility. One of the items in this program is "education-information," which provided an opportunity to integrate our education plan into the patient's electronic file.

The advanced practice nurse, the head nurse, and specialized transplant nurses started discussing the setup by composing a paper version of the education program (see Table). This document was sent to a team of information technology engineers, who transferred the paper version of the education program to the patient's electronic file.

A pilot study of the education program was conducted for 2 months starting in August 2009. The program was used in 9 patients who received a lung transplant during this period. Initially, no time schedule was used in the program, which led to an accumulation of topics that still needed to be covered when patients were almost ready for discharge. A lot of information needed to be given in the last days of hospitalization, making patients feel overwhelmed with information. Also, in the beginning, access to the program was restricted to nurses and physicians only, which clearly demonstrated the need to expand access to physiotherapists, dieticians, psychologists, and social workers.

To maximally reduce the variability within the information provided by different professionals, not only the overarching topic that needs to be addressed should be indicated in the file (eg, dental care), but also the specific content about a particular topic (eg, brushing and flossing 2 times a day). Besides following a checklist to ensure that each specific content area is addressed, professionals need to be able to evaluate knowledge regarding each crucial element of education separately. By doing so, health care workers know precisely which information is not known, partially known, or completely known. When they register that the information is "completely known" by the patient, the item disappears from the list and is moved to the bottom of the page. By doing so, a clear distinction between topics that are understood by the patients and topics that need to be addressed (further) can be made.

After several rounds of adaptations and pilot testing, the program was implemented in the electronic files of all new transplant patients in October 2009.

\section{Results}

At the end of the hospitalization period, most patients indicated that they feel confident enough to go home. The health care providers acknowledged having a better idea about where each patient stands in the education process and were more confident that all necessary information had been given to the patient. The program leads to a higher level of uniformity, which means that each patient gets the same information from each health care provider. The information given to a patient is no longer subject to the person who provides the information.

Health care providers also appreciate the easy access to the program. All health care workers involved in the lung transplant program now have access to the electronic file. In this way, it becomes clearer who is responsible for a given topic, facilitating a shared-care approach. This arrangement leads to a higher level of transparency such that certain topics are not forgotten and overlap can be avoided. Although no formal evaluation has been conducted, the data show that both patients and professionals are very satisfied with the electronic educational plan.

\section{Discussion}

Education of the health care providers as well as the transplant recipients is recognized as one of the most important goals in transplant medicine..$^{5,12,14-16}$ Structured education plans have not been published, however, leaving transplant professionals a bit puzzled about how best to educate their patients.

Our program for the first time provides structure and guidance to all health care providers involved in lung transplant. Our standardized evidence-based education program led to an increased level of confidence within our lung transplant population, greater uniformity and transparency, and a high level of satisfaction with the program among the members of the transplant team.

Other transplant centers or organ transplant programs would most likely also benefit from our education plan, as the topics to be addressed before discharge are very similar across organ domains. In our hospital, a working group consisting of nurses from the different transplant programs was established in 2010; it is called the "Transplantation Innovation Team 
(TRANSIT)." One of the group's aims was to share knowledge on educational approaches and harmonize education across transplant groups. Given that many transplant patients undergo multiple transplants (eg, kidney transplant after lung transplant), such sharing of knowledge has major advantages for both patients and professionals.

The TRANSIT team realizes, however, that education presents only the fundamentals for effective posttransplant management; other steps are needed to transition from knowledge to self-management by patients within their daily life. Further goals refer to creating a screening instrument to formally evaluate patients' knowledge about the posttransplant regimen. Evaluation is now done by the team members, using the electronic platform, yet a more structured approach would be helpful. Unfortunately, no such instrument is available in the literature. Our group is currently developing a self-report instrument for evaluating knowledge that will be tested in the future.

Next, apart from medication management, our program is focused almost exclusively on providing information. Although providing this information is crucial to guaranteeing good self-management, information alone is usually not sufficient. TRANSIT is currently developing programs to train patients in acquiring the necessary self-management skills.

We also need to acknowledge that the way patients learn can vary widely. Some patients learn better by reading information, whereas others may be auditory or experiential learners. Goals for the future are to approach these differences in learning styles so that we can provide education that is based on patients' individual learning needs. Therefore, we are currently developing a secured web application in which information tailored to a particular patient can be provided. This information consists of written brochures, videos, questionnaires, and so on. Thus patients have the opportunity to receive information that is based on their personal needs any time they want it by using the learning method that they feel most comfortable with.

Although future steps to improve education are essential, our electronic education plan provides a unique contribution to the literature and clinical practice, as it highlights what every transplant patient needs to know and might serve as a guide to shape the content and structure of education materials and programs in other national and international transplant programs.

\section{Acknowledgments}

The authors sincerely thank the following people for their outstanding contributions to the development and implementation of our education program: D. Delva, V. Lemaigre, P. Baeten, A. Cattaert, R. Droogmans, Prof Dr L. Dupont, Prof Dr D. Van Raemdonck, and the nursing staff of unit 650 Pneumology, University Hospitals of Leuven.

\section{References}

1. Avery RK. Infections after lung transplantation. Semin Respir Crit Care Med. 2006;27(5):544-551.

2. Bjortuft O, Johansen B, Boe J, Foerster A, Holter E, Geiran $\mathrm{O}$. Daily home spirometry facilitates early detection of rejection in single lung transplant recipients with emphysema. Eur Respir J. 1993;6(5):705-708.

3. Chisholm MA. Issues of adherence to immunosuppressant therapy after solid-organ transplantation. Drugs. 2002; 62(4):567-575.

4. Dew MA, DiMartini AF, De Vito Dabbs A, et al. Rates and risk factors for nonadherence to the medical regimen after adult solid organ transplantation. Transplantation. 2007; 83(7):858-873.

5. Husain AN, Siddiqui MT, Holmes EW, et al. Analysis of risk factors for the development of bronchiolitis obliterans syndrome. Am J Respir Crit Care Med. 1999;159(3): 829-833.

6. Knoop C, Estenne M. Acute and chronic rejection after lung transplantation. Semin Respir Crit Care Med. 2006;27(5): 521-533.

7. Kugler C, Fischer S, Gottlieb J, et al. Symptom experience after lung transplantation: impact on quality of life and adherence. Clin Transpl. 2007;21(5):590-596.

8. Langer D, Gosselink R, Pitta F, et al. Physical activity in daily life 1 year after lung transplantation. J Heart Lung Transplant. 2009;28(6):572-578.

9. Ortega T, Deulofeu R, Salamero P, et al. Health-related quality of life before and after a solid organ transplantation (kidney, liver, and lung) of Four Catalonia Hospitals. Transplant Proc. 2009;41(6):2265-2267.

10. Studer SM, Levy RD, McNeil K, Orens JB. Lung transplant outcomes: a review of survival, graft function, physiology, health-related quality of life and cost-effectiveness. Eur Respir J. 2004;24(4):674-685.

11. Bodenheimer T, Lorig K, Holman H, Grumbach K. Patient self-management of chronic disease in primary care. JAMA. 2002;288(19):2469-2475

12. Holman H, Lorig K. Patient self-management: a key to effectiveness and efficiency in care of chronic disease. Public Health Rep. 2004;119(3):239-243.

13. Lorig KR, Holman H. Self-management education: history, definition, outcomes, and mechanisms. Ann Behav Med. 2003; 26(1):1-7.

14. Bahruth AJ. What every patient should know... Pretransplantation and posttransplantation. Crit Care Nurs Q. 2004; 27(1):31-60.

15. Morrissey PE, Flynn ML, Lin S. Medication non-compliance and its implications in transplant recipients. Drugs. 2007;67(10):1463-1481.

16. Wilkins F, Bozik K, Bennett K. The impact of patient education and psychosocial supports on return to normalcy 36 months post kidney transplant. Clin Transplant. 2003;17(suppl 9): 78-80. 